\title{
Retentivity as an Indicator of the Capacity of Basins without an Outlet to Accumulate Water Surpluses
}

\author{
Maciej Major ${ }^{1}$, Roman Cieśliński* \\ 'Institute of Geoecology and Geoinformation, Adam Mickiewicz University in Poznan, Poland \\ ${ }^{2}$ Department of Hydrology, Gdansk University, Poland
}

Received: May 14, 2015

Accepted: June 23, 2015

\begin{abstract}
The initial hypothesis assumed in our research was that an improvement in the water cycle in the river catchments chosen for analysis could be obtained using their natural basins without outlets to store rainwater from natural and urbanised areas. The chief goal of the research was to identify the types and conditions of retention in each of the catchments. Fieldwork was carried out in the catchments of the upper Parsęta and the Potok Oliwski, rivers situated in the Baltic drainage area in the coastal zone of northern Poland.

The upper Parsęta catchment includes an abundance of depressions without outlets, where a total of 358 landforms with no surface runoff have been distinguished, or 4.84 per $1 \mathrm{~km}^{2}$. Of this number 164 are absorptive basins and 194 are closed evapotranspiration basins. The distinguished closed basins take up a substantial proportion of the upper Parsęta catchment at $8.33 \mathrm{~km}^{2}$, or $11.26 \%$. The Potok Oliwski catchment includes depressions without outlets, where a total of 35 landforms with no surface runoff have been distinguished, or 4.83 per $1 \mathrm{~km}^{2}$. Of this number, 27 are absorptive basins. Closed basins occupy a total of $82,565 \mathrm{~m}^{2}$, or $1.14 \%$ in the upper Potok Oliwski catchment.

The total capacity of all the closed basins in the upper Parsęta catchment amounted to $6,292,160.89 \mathrm{~m}^{3}$. In turn, in the Potok Oliwski catchment the total volume of closed evapotranspiration basins was $1,677.1 \mathrm{~m}^{3}$, and when filled with water, absorptive basins would have a total volume of $23,182.8 \mathrm{~m}^{3}$.

The result is considerable potential reservoirs in both catchments. Young glacial catchments, particularly areas with no outlet, can be a place of existing surplus drinking water. Water retention is a significant potential with more and more apparent water shortage in the world.
\end{abstract}

Keywords: basins without outlets, water resources, retentive function, meteorological conditions

\section{Introduction}

Water resources on Earth are huge, at about 1.4 billion $\mathrm{km}^{3}$. They include surface- and groundwater. Unfortunately, a large proportion is not fit for use by humans, whether for industrial purposes or for consumption, owing to their contamination, salinity, or capture in glaciers and ice-sheets.

*e-mail: georc@univ.gda.pl
Large water resources are also untapped because of their lack of a hydrological link with the principal river systems $[1,2]$. This especially concerns areas without outlets, which account for about $20 \%$ of the land area of the globe [3]. In times of dwindling water resources, they should be used increasingly as a potential source of water for humans. Such areas are retentive bodies nourished primarily in a vertical pattern - one of their two chief alimentation elements being precipitation. The depressions under study can 
retain substantial amounts of rain, even torrential, over a very short time [4].

The water deficit observed in many regions of the globe, including Poland, forces people to seek places where they could tap new resources or apply some technological measures to recover substantial amounts of water that have so far figured as losses in the total balance. One of the latter is employing natural retention to store and then recover water. This can involve not only the surface water cycle, but also the near-surface one [5]. Among the natural objects that can be employed to store precipitation and then be used for household and economic purposes are basins without outlets, both of the absorptive and the evapotranspiration type $[6,7]$. All kinds of practices, both technological (small water reservoirs, weirs, gates, etc.) and non-technological (afforestation, tree planting, protective vegetation belts, protection of kettle ponds, country ponds, marshes, etc.) can help to slow down or stop water while restoring the natural landscape. However, to be able to employ the various forms of retention correctly, one should first identify the conditions that will affect small water cycles and the magnitude of retention in the catchments $[8,9]$.

The occurrence of closed basins has a substantial impact on the present-day character of the water cycle in a river basin since they create special circulation conditions and offer a natural possibility of rainwater retention $[5,8$, 9]. This is more important as Poland's water resources are modest when compared with other European countries [10], and the amount of water at our disposal largely depends on precipitation $[11,12]$. This implies the possibility of retention of rainwater from built-up areas. Do not forget at the same time that water resources will be reduced as a result of climate change [13-15]. Also important will be the state of water quality and local, regional, and how global factors influence them [16-18].

The initial hypothesis assumed in the research was that an improvement in the water cycle in the river catchments chosen for analysis could be obtained by using their natural basins without outlets to store rainwater from natural and urbanised areas. The chief goal of the research was to identify the types and conditions of retention in each catchment. At this stage it was extremely important to estimate the magnitude of water retention in the individual closed basins and to assess the possibility of this water being used by humans.

Fieldwork was carried out in the catchments of the upper Parsęta and the Potok Oliwski (Fig. 1), rivers situated in the Baltic drainage area in the coastal zone of northern Poland.

The upper Parsęta catchment (Fig. 2), a geoecosystem of a lowland postglacial area situated in the temperate zone, is representative of the region of Pomerania. Displaying a marked relative relief, it extends on the northern slope of the Central Pomeranian end-morainic series within the socalled Parsęta lobe. Its relief results from complex deglaciation during the Pomeranian Stage of the Vistulian and during the Holocene morphogenetic cycle [19]. The basic part of the catchment is located within the outer subzone of the dead-ice moraine and kame moraine [20].

In the catchment, surface deposits include glacial tills, sands, and gravels, as well as slope and mineral-organic deposits. Agriculture and forestry are the predominant land uses, while the soils are mostly brown with an admixture of black soils, muds, and mineral-organic and organic soils. The upper Parsęta catchment occupies an area of $74.0 \mathrm{~km}^{2}$, and the river has a length of $13.26 \mathrm{~km}$. Basins without outlets have a special place in the contemporary denudation system of the upper Parsęta catchment; they display a variety of sizes, morpholithology, and location (with respect to other landforms) [21].

A characteristic feature not only of the upper Parsęta catchment, but the river's entire drainage basin, is the presence of a great number of closed basins. Combined with a large proportion of podzolic soils, this creates good conditions for efficient infiltration and increases retentivity in the catchment, as pointed out, among others, by Choiński [22] and Szpikowski [23].

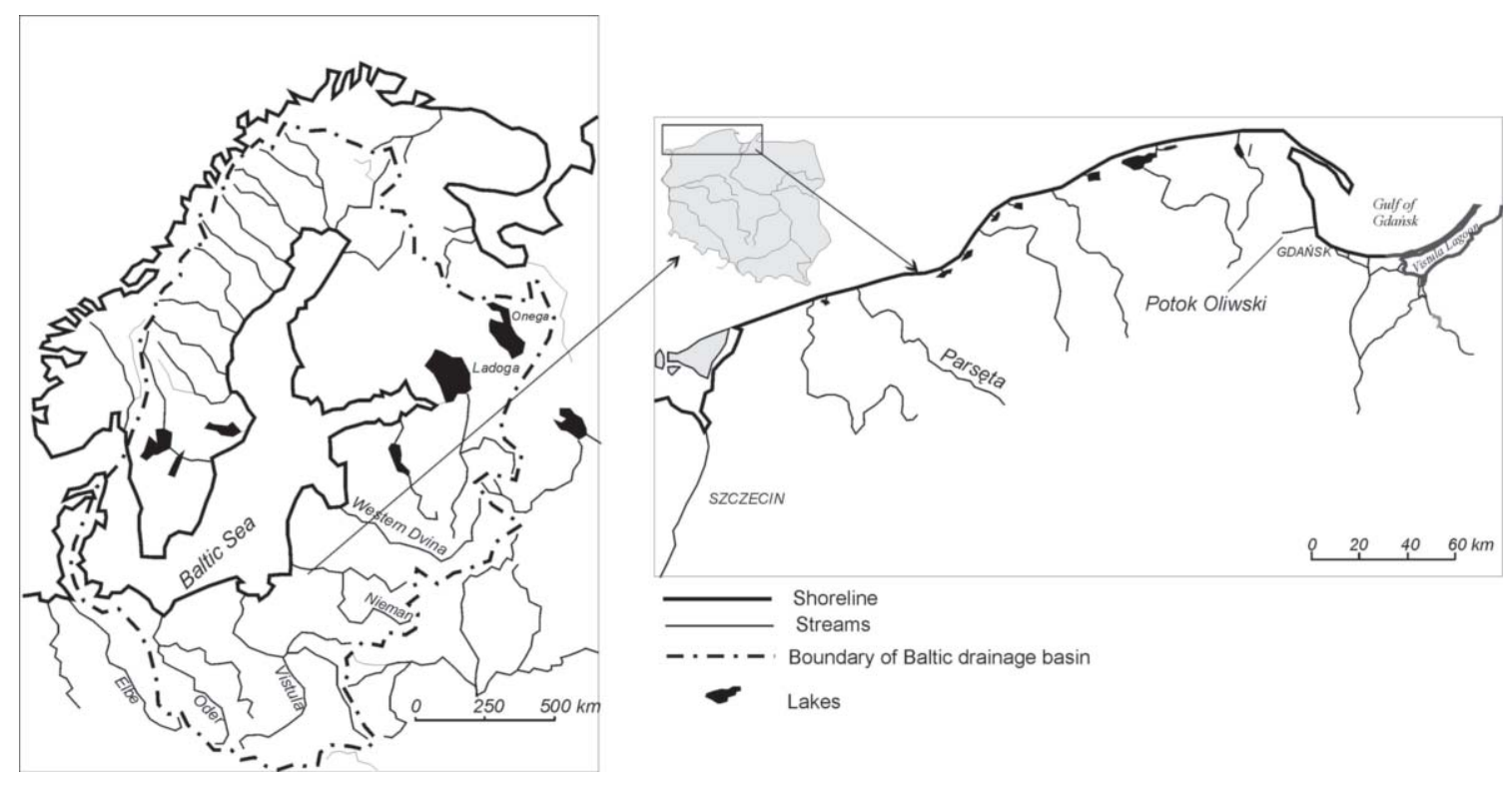

Fig. 1. Location of the catchments under study. 


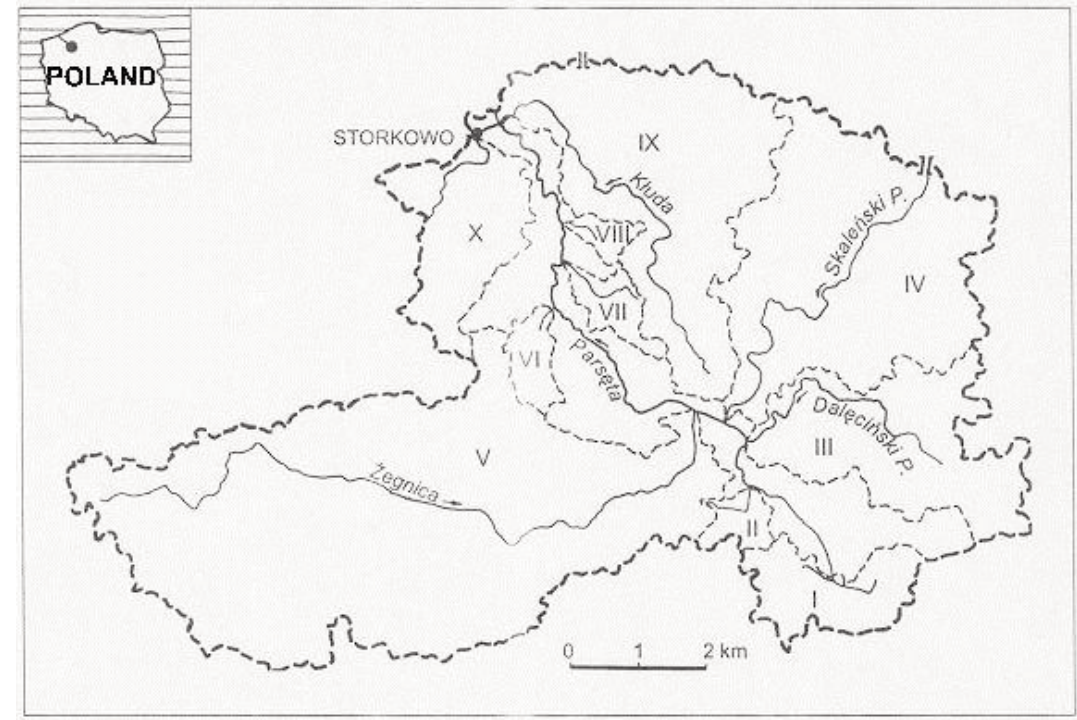

Fig. 2. Upper Parsęta catchment.

The upper reaches of the Potok Oliwski catchment occupy $7.25 \mathrm{~km}^{2}$, the greatest part of which, $2.71 \mathrm{~km}^{2}$, is covered by woodland. It is densely built, mostly with housing estates as well as industrial facilities and large-lot shopping centres occupying a total of $1.45 \mathrm{~km}^{2}$ (Fig. 3). Built-up areas often suffer from the underdevelopment of infrastructure in the form of storm water drainage and storage reservoirs suited to the road area. This part of the Potok Oliwski catchment lacks an organised network of surface waters. Among its surface hydrographic elements are marshes, lakes, and the most characteristic ones: numerous areas without an outlet with kettle ponds located at the bottom. Here the catchment is drained via streams of the marginal zone, which offers a good pathway for the outflow of surface waters owing to its digitally branched valleys. Some of the valleys, however, remain dry, providing a route for potential rain- and meltwater, and some fill with intermittent streams that develop in spring and autumn.

The principal streams of the catchment are the Potok Oliwski together with its tributaries (Fig. 4). The Potok Oliwski shows a high mean gradient reaching up to $12.5 \%$, and in the marginal zone this figure even exceeds $20 \%$.

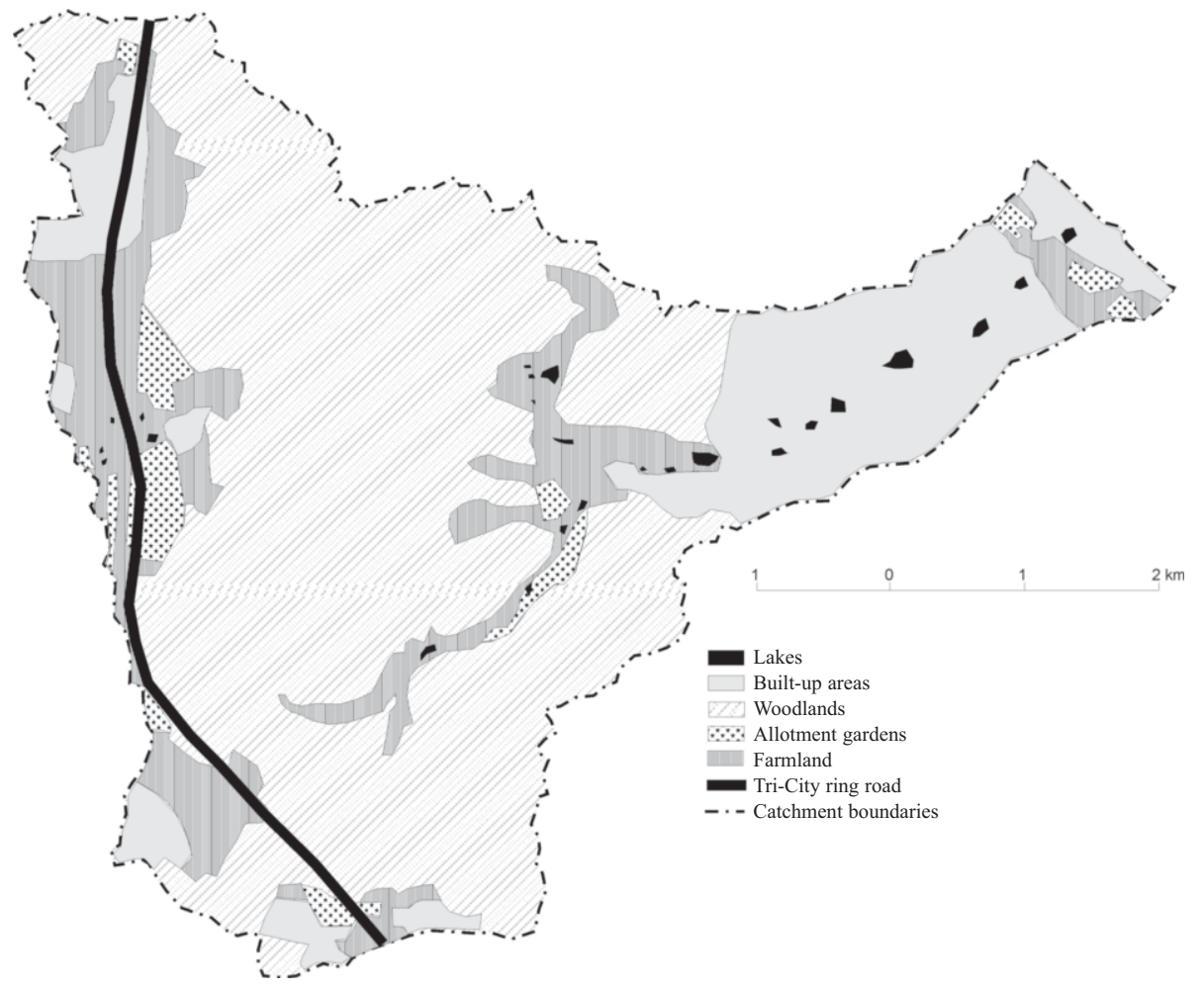

Fig. 3. Land-use pattern in the Potok Oliwski catchment. 
In 2006-08, discharges in the stream ranged from $0.01 \mathrm{~m}^{3} \cdot \mathrm{s}^{-1}$ to $0.41 \mathrm{~m}^{3} \cdot \mathrm{s}^{-1}$ [24]. A tendency could be observed for the discharges to increase from year to year, which is believed to be caused by the growing amount of water that reaches the streams of the catchment from storm sewers in built-up areas. In its lower reaches the Potok Oliwski is fully improved and accompanied by several retention reservoirs and ponds, constructed here already since the Cistercian times. Discharged into the stream is rainwater from the residential quarters situated in the area.

\section{Methods}

The proposal of research on areas without an outlet in a systems approach rests on the conception of a geoecosystem based on Bertalanffy's general systems theory [25]. In accordance with it, basins without outlets together with their catchments can be regarded as variously sized spatial units representing a variety of landscapes and should be defined as territorial systems. The systems research methodology has been backed up by American studies [26].

The basic methodological assumption adopted in the research was the conception proposed by Drwal [27] of distinguishing two types of area differing in ways of water circulation: a closed absorptive type, where the chief precipitation-balancing process is infiltration, and a closed evapotranspiration type, where the chief precipitationbalancing process is evaporation. A depression of the latter type is usually filled with water and then becomes a kettle pond or a marsh. Both types were the object of detailed analyses.
The research focused mainly on indoor work and involved an analysis of topographic maps, statistical calculations, and the interpretation of the results of meteorological measurements. The documentary material employed was topographic base maps at a scale of 1:10,000, and in the case of the Potok Oliwski, hydrographic maps at a scale of 1:50,000 (sheets 3449D Gdańsk-Osowa and 3450C Gdańsk). The basic method was an analysis of the topographic maps and the statistical processing of the material collected using ArcGIS.

In the upper Parsęta catchment, the chief criterion of distinguishing closed absorptive basins was the assumption that they were concave landforms, closed on a map with a double contour line, the tick mark pointing inwards. The analyses of this area also covered all evapotranspiration basins without outlets that could be distinguished on the basis of the topographic base maps available.

For the purposes of this study, four parameters were necessary: the length, width, depth, and area of the closed basins. The length of a basin was measured as the distance in a straight line between the two farthest points of its margin. In turn, its width was measured as a perpendicular to the length, again joining two farthest points of its margin in a straight line. Depth was calculated by subtracting half a contour interval from the lowest-situated closed contour line on a map at a scale of $1: 10,000$, or $0.625 \mathrm{~m}$. This parameter shows a high level of generalisation resulting from calculation methods employing topographic base maps.

The retentive potential of closed absorptive and evapotranspiration basins was calculated from the formulas for a total capacity of water bodies proposed by Penck, of the form presented below:

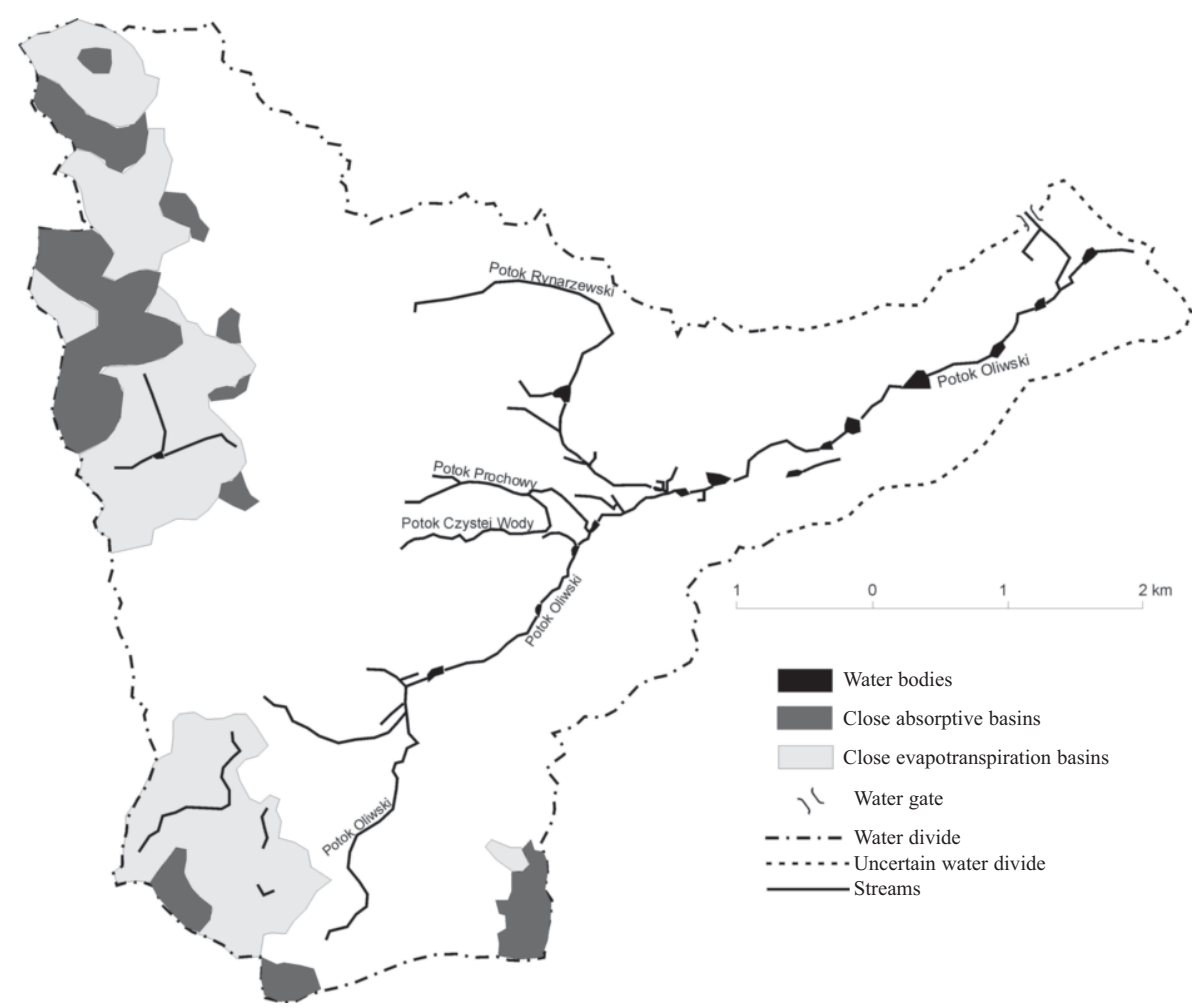

Fig. 4. Potok Oliwski catchment. 


$$
V=1 / 3 \times P \times h
$$

...where: $V$ is the volume of the cone, $P$ is the area of its base, and $h$ is the height of the cone (here: the depth of the depression).

In the case of a depression for which only one parameter was available - area or depth - further statistical analysis proved necessary. To this end, trend lines were plotted for a specified group of basins, and equations of curves were formulated that were linear functions of the type $y=a x+b$. After a suitable transformation, equations in one unknown were obtained which allowed the calculation of the parameters sought. Such a statistical estimation of one of the parameters was necessary to calculate the retentive potential of the closed basins under study.

The meteorological conditions during the analysed period were identified on the basis of the results of studies carried out at the Adam Mickiewicz University Geoecological Station at Storkowo and a measuring station near the Gdańsk Refinery. This was a continuous record by a MILOS 500 automatic station. Meteorological monitoring embraced measurements of air temperature and the amount and distribution of precipitation. Those were considered key variables for the characterisation of the operation and retentive capacities of the geoecosystems of closed basins in the upper Parsęta and Potok Oliwski catchments.

\section{Results and Discussion}

There is an abundance of depressions without outlets in the upper Parsęta catchment, where a total of 358 landforms with no surface runoff have been distinguished, or 4.84 per $1 \mathrm{~km}^{2}$. Of this number, 164 are absorptive basins, or 2.22 per $1 \mathrm{~km}^{2}$. In turn, closed evapotranspiration basins are concave landforms with small water bodies at the bottom (kettle ponds or marshes), and they amount to 194, or 2.62 per $1 \mathrm{~km}^{2}$.

The distinguished closed basins take up a substantial proportion of the upper Parsęta catchment at $8.33 \mathrm{~km}^{2}$, or $11.26 \%$. Most of it is occupied by absorptive basins at $4.26 \mathrm{~km}^{2}$, or $5.76 \%$, while evapotranspiration ones account for $4.07 \mathrm{~km}^{2}$, or $5.5 \%$ [26].

The depressions with small kettle ponds are largely grouped in the northern, western, and southwestern parts of the catchment, while absorptive basins are evenly distributed throughout the area $[6,7]$.

A feature typical of postglacial areas is basins without an outlet [28]. What favours their occurrence in the upper Potok Oliwski catchment is a relief of hills and depressions with gentle slopes. The absence of an organised surface runoff and the postglacial geological structure of the substratum give rise to two kinds of closed basins absorptive and evapotranspiration ones. There are eight basins of the former type in the catchment and 27 of the latter type (Fig. 5).

The Potok Oliwski catchment includes depressions without outlets, where a total of 35 landforms with no surface runoff have been distinguished, or 4.83 per $1 \mathrm{~km}^{2}$.
Of this number, 27 are absorptive basins. In turn, closed evapotranspiration basins amount to 177. Closed basins occupy a total of $82,565 \mathrm{~m}^{2}$ (or 1.14\%) in the upper Potok Oliwski catchment, of which evapotranspiration ones account for $7,810 \mathrm{~m}^{2}$. The area of closed absorptive basins ranges from 320 to $12,500 \mathrm{~m}^{2}$, and of evapotranspiration ones from 450 to $2,800 \mathrm{~m}^{2}$. Depth varies between 0.30 and $1.30 \mathrm{~m}$ for absorptive ones ( $0.65 \mathrm{~m}$ on average) and between 0.45 and $0.80 \mathrm{~m}$ for evapotranspiration ones $(0.58 \mathrm{~m}$ on average). The area, depth, and volume data of all the basins in the Potok Oliwski catchment are presented in Table 1.

To present natural conditions directly affecting the retentive potential of the closed basins, let us consider atmospheric precipitation supplying their catchments. For issues involving the water cycle in a catchment, weather conditions in the given hydrological year have to be considered. The years when the research was conducted, 2006 and 2007, differed in terms of temperature and precipitation. In accordance with the classification prepared for the purposes of the Integrated Monitoring of the Natural Environment in Poland, they can be described as follows:

- 2006 was normal in thermal terms and dry in terms of precipitation: the mean temperature was $7.7^{\circ} \mathrm{C}$ and the annual rainfall $603.9 \mathrm{~mm}$ (Fig. 6)

- 2007 was widely different: it was warm with a mean air temperature of $9.4^{\circ} \mathrm{C}$, and wet with an annual rainfall of $855.2 \mathrm{~mm}$ (Fig. 6)

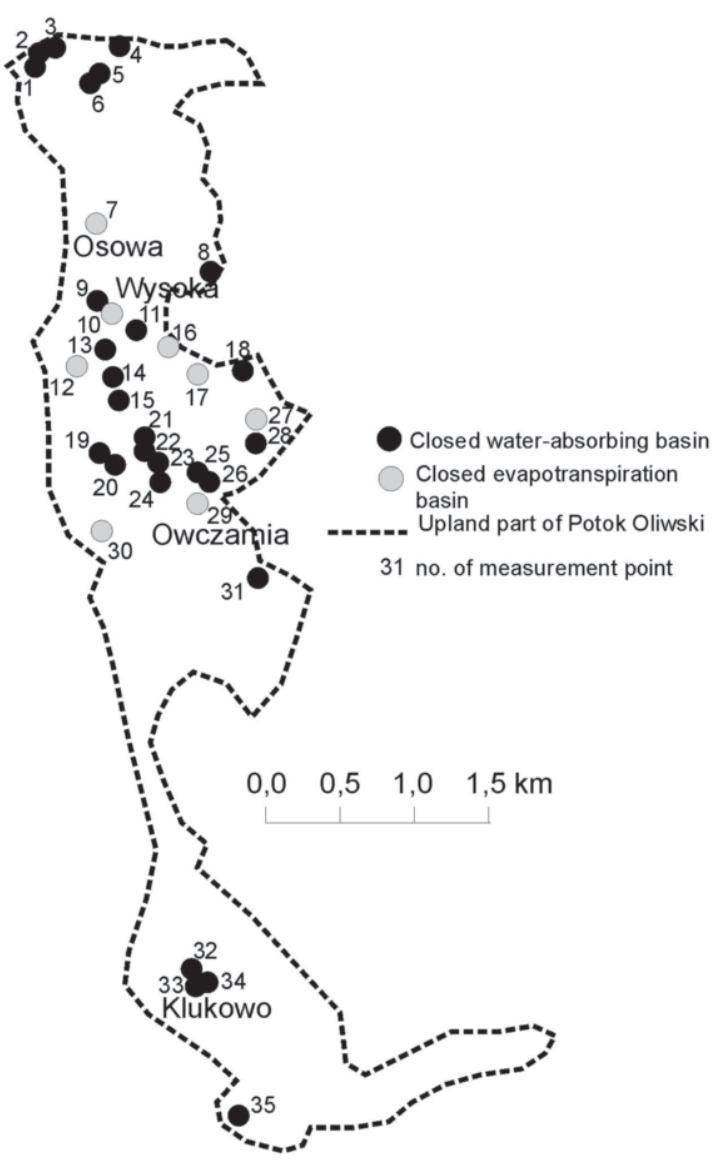

Fig. 5. Basins without outlets in the upland part of Potok Oliwski. 
Table 1. Morphometric characteristics of closed basins in the upper reaches of the Potok Oliwski catchment.

\begin{tabular}{|c|c|c|c|c|}
\hline $\begin{array}{c}\text { No. of } \\
\text { depressions }\end{array}$ & Depression type & $\begin{array}{l}\text { Area } \\
{\left[\mathrm{m}^{2}\right]}\end{array}$ & $\begin{array}{l}\text { Depth } \\
{[\mathrm{m}]}\end{array}$ & $\begin{array}{c}\text { Volume } \\
{\left[\mathrm{m}^{3}\right]}\end{array}$ \\
\hline 1 & Absorptive & 550 & 0.50 & 90.75 \\
\hline 2 & Absorptive & 420 & 0.40 & 55.44 \\
\hline 3 & Absorptive & 630 & 0.50 & 103.95 \\
\hline 4 & Absorptive & 500 & 0.38 & 62.70 \\
\hline 5 & Absorptive & 480 & 0.42 & 66.53 \\
\hline 6 & Absorptive & 320 & 0.45 & 47.52 \\
\hline 7 & Evapotranspiration & 590 & 0.50 & 97.35 \\
\hline 8 & Absorptive & 9,000 & 0.60 & $1,782.00$ \\
\hline 9 & Absorptive & 660 & 0.44 & 95.83 \\
\hline 10 & Evapotranspiration & 700 & 0.50 & 115.50 \\
\hline 11 & Absorptive & 520 & 0.60 & 102.96 \\
\hline 12 & Evapotranspiration & 1,080 & 0.60 & 213.84 \\
\hline 13 & Absorptive & 12,000 & 0.70 & $2,772.00$ \\
\hline 14 & Absorptive & 8,800 & 1.05 & $3,049.20$ \\
\hline 15 & Absorptive & 5,200 & 1.20 & $2,059.20$ \\
\hline 16 & Evapotranspiration & 450 & 0.50 & 74.25 \\
\hline 17 & Evapotranspiration & 590 & 0.60 & 116.82 \\
\hline 18 & Absorptive & 350 & 0.30 & 34.65 \\
\hline 19 & Absorptive & 500 & 0.30 & 49.50 \\
\hline 20 & Absorptive & 380 & 0.40 & 50.16 \\
\hline 21 & Absorptive & 650 & 0.55 & 117.98 \\
\hline 22 & Absorptive & 440 & 0.40 & 58.08 \\
\hline 23 & Absorptive & 370 & 0.66 & 80.59 \\
\hline 24 & Absorptive & 600 & 0.37 & 73.26 \\
\hline 25 & Absorptive & 720 & 0.50 & 118.80 \\
\hline 26 & Absorptive & 805 & 1.00 & 265.65 \\
\hline 27 & Evapotranspiration & 600 & 0.45 & 89.10 \\
\hline 28 & Absorptive & 410 & 0.52 & 70.36 \\
\hline 29 & Evapotranspiration & 1,000 & 0.70 & 231.00 \\
\hline 30 & Evapotranspiration & 2,800 & 0.80 & 739.20 \\
\hline 31 & Absorptive & 550 & 0.60 & 108.90 \\
\hline 32 & Absorptive & 2,800 & 0.95 & 877.80 \\
\hline 33 & Absorptive & 6,600 & 1.25 & $2,722.50$ \\
\hline 34 & Absorptive & 8,000 & 1.10 & $2,904.00$ \\
\hline 35 & Absorptive & 12,500 & 1.30 & $5,362.50$ \\
\hline
\end{tabular}

The differences in the thermal and precipitation conditions between the two years were reflected in variations in the levels of surface- and groundwater and hence in the retentive potential of the closed basins, and differences in the rainfall itself, in the loads of solutes reaching the geoecosystems of their catchments.

The difference in the mean annual temperature amounted to $1.7^{\circ} \mathrm{C}$ between the two years. Usually, the warmest month of the year is July. This was so also in July 2006, when the highest mean monthly temperature was recorded, at $21.1^{\circ} \mathrm{C}$. A year later, in the three summer months of June, July, and August, the temperature stayed at $17^{\circ} \mathrm{C}$ or slightly higher (Table 2). High air temperatures enhance evaporation and hence caused a drop in the level of surface- and groundwater in the depressions studied. This means that the best storage conditions occur in the summer half-year: in the case of any extreme events, the depressions are ready to accept water to their full capacity.

In two years the lowest mean monthly temperatures were recorded in different months. In 2006 the coldest one proved to be January with a mean monthly temperature of $-6.5^{\circ} \mathrm{C}$. Two other months displayed sub-zero mean temperatures, too - namely February $\left(-1.6^{\circ} \mathrm{C}\right)$ and March $2006\left(-1.0^{\circ} \mathrm{C}\right)$. In 2007 it was only in February that the mean monthly temperature fell below zero, to $-0.2^{\circ} \mathrm{C}$ (Table 1).

Precipitation in Poland largely comes from the moisture absorbed over the Atlantic Ocean by air masses transported together with cyclonic systems by the westerly winds prevailing throughout the year [29]. With cyclonic activity vigorous year round, precipitation is recorded in all seasons. Precipitation totals are markedly higher in summer than in winter; the proportion has been found to be roughly $60: 40 \%$. Summer rains vary greatly; there are lasting dry periods, especially toward the end of summer in August, September, and October [6]. Those dates coincide with the depletion of surface waters from ephemeral ponds.

As in the case of thermal conditions, the two years under study differed substantially in terms of precipitation; both also departed from the multi-year mean $(670.6 \mathrm{~mm})$ calculated for 1963-1982 at Szczecinek station in West Pomerania. The year 2006 was dry, and 2007 was wet (Table 3).

The highest monthly rainfall total reached $154.0 \mathrm{~mm}$ and occurred in August 2006. The figure exceeded $100 \mathrm{~mm}$ three more times over the study period, with $139.8 \mathrm{~mm}$ in January, $132.9 \mathrm{~mm}$ in June, and $134.8 \mathrm{~mm}$ in July 2007 (Table 3).

The lowest monthly rainfall total, a mere $9.6 \mathrm{~mm}$, was recorded in January 2006. Only one more time was this figure smaller than $20 \mathrm{~mm}$, in October 2007, when it was equal to $17.6 \mathrm{~mm}$ (Table 2).

Table 2. Mean monthly air temperatures in the upper Parsęta catchment in hydrological years 2006-07.

\begin{tabular}{|c|c|c|c|c|c|c|c|c|c|c|c|c|c|}
\hline Hydrological year & XI & XII & I & II & III & IV & V & VI & VII & VIII & IX & X & Mean \\
\hline 2006 & 3.1 & 0.0 & -6.5 & -1.6 & -1.0 & 6.9 & 12.2 & 16.3 & 21.1 & 16.3 & 14.8 & 10.3 & 7.7 \\
\hline 2007 & 6.4 & 4.9 & 3.5 & -0.2 & 5.6 & 8.4 & 13.7 & 17.5 & 17.0 & 17.1 & 12.0 & 6.4 & 9.4 \\
\hline
\end{tabular}


Table 3. Monthly rainfall in the upper Parseta catchment in hydrological years 2006-07.

\begin{tabular}{|c|c|c|c|c|c|c|c|c|c|c|c|c|c|}
\hline Hydrological year & XI & XII & I & II & III & IV & V & VI & VII & VIII & IX & X & Total \\
\hline 2006 & 36.3 & 115.4 & 9.6 & 27.1 & 32.1 & 29.1 & 73.2 & 38.3 & 22.9 & 154.0 & 44.2 & 21.7 & 603.9 \\
\hline 2007 & 66.0 & 45.3 & 139.8 & 38.5 & 36.0 & 21.3 & 98.2 & 132.9 & 134.8 & 45.5 & 79.3 & 17.6 & 855.2 \\
\hline
\end{tabular}

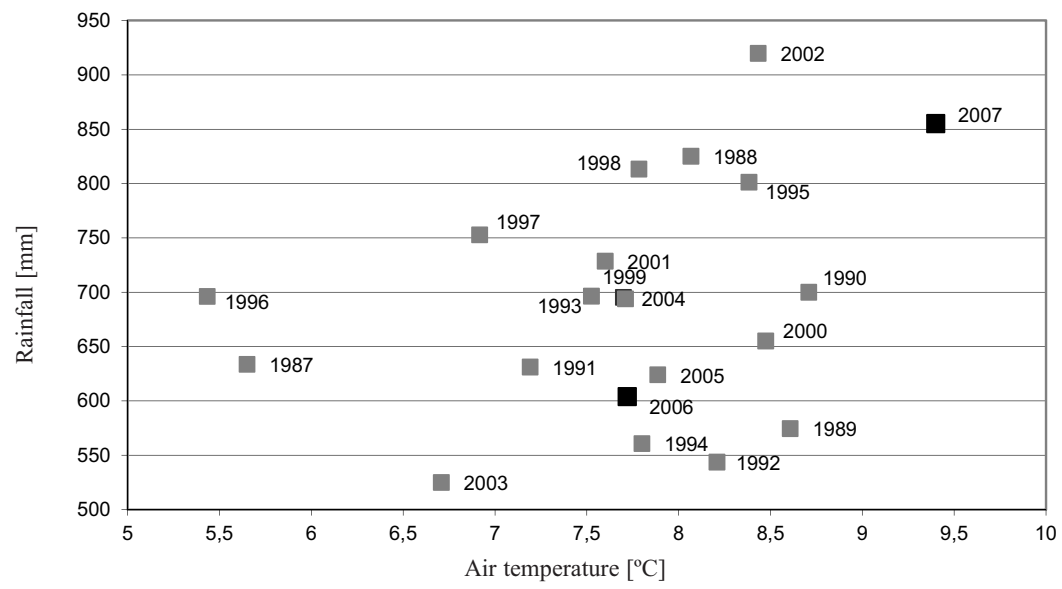

Fig. 6. Thermal and precipitation conditions at Storkowo in the hydrological years 2006-07 as compared with the multi-year period 1987-2005.
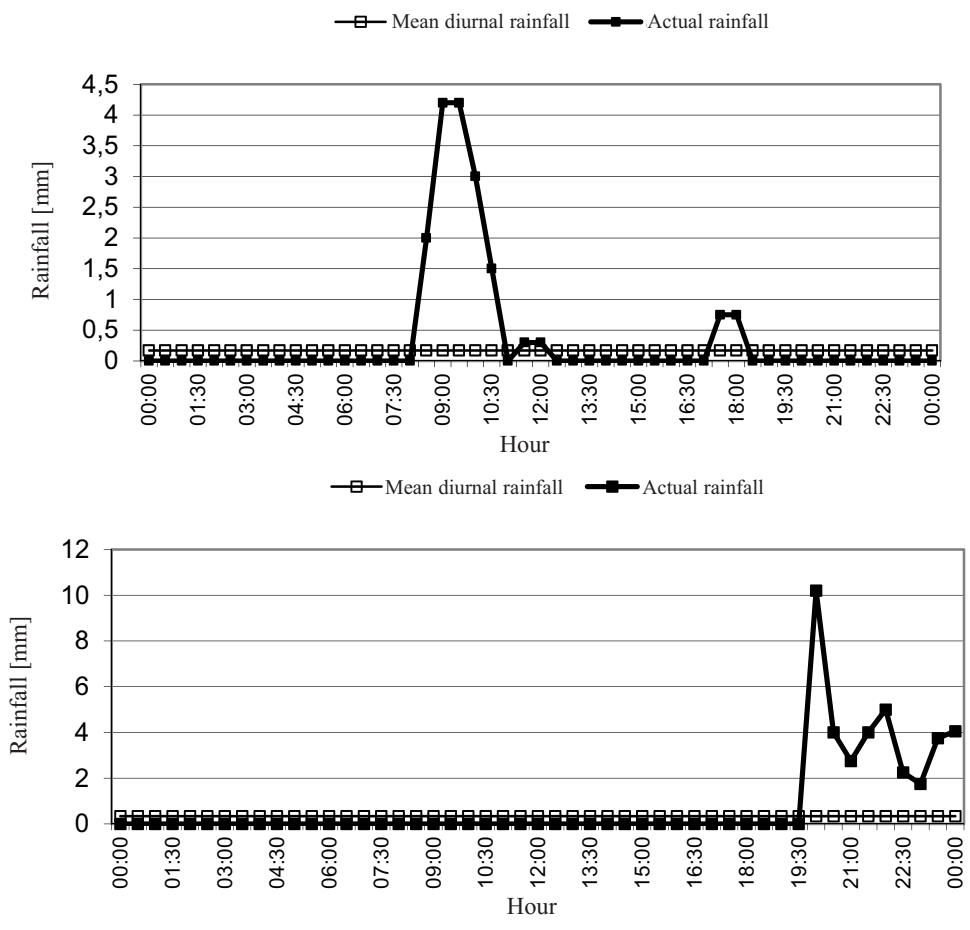

$\longrightarrow$ Mean diurnal rainfall $\longrightarrow$ Actual rainfall

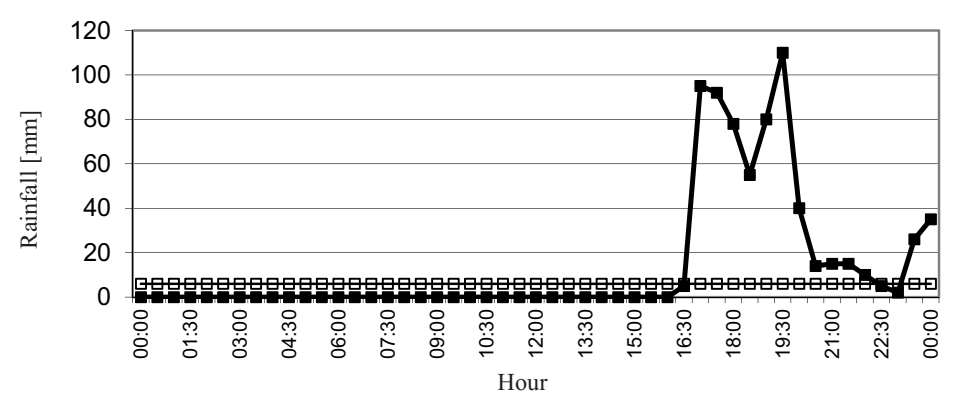

Fig. 7. Precipitation on 18 February, 12 March, and 9 July 2001 [24]. 
Table 4. Amount of water in the upper part of the Potok Oliwski catchment depending on precipitation intensity.

\begin{tabular}{|c|c|c|c|c|}
\hline Type of precipitation & Water volume & Diurnal rainfall & Max. intensity & Mean diurnal rainfall \\
\hline Normal: 18 Feb. 2001 & $30,450 \mathrm{~m}^{3}$ & $4.05 \mathrm{~mm}$ & $4.2 \mathrm{~mm} / \mathrm{h}$ - normal precipitation & $0.17 \mathrm{~mm}$ \\
\hline Heavy: 12 March 2001 & $73,950 \mathrm{~m}^{3}$ & $8.25 \mathrm{~mm}$ & $10.2 \mathrm{~mm} / \mathrm{h}$ - heavy precipitation & $0.34 \mathrm{~mm}$ \\
\hline Torrential: 9 July 2001 & $804,750 \mathrm{~m}^{3}$ & $143.7 \mathrm{~mm}$ & $111.0 \mathrm{~mm} / \mathrm{h}-$ torrential precipitation & $5.99 \mathrm{~mm}$ \\
\hline
\end{tabular}

Table 5. Retentive capacities of closed basins in the upper Parsęta catchment.

\begin{tabular}{|c|c|c|c|c|}
\hline \multirow{2}{*}{ Parameter } & \multicolumn{4}{|c|}{$\mathrm{V}\left[\mathrm{m}^{3}\right]$} \\
\cline { 2 - 5 } & \multirow{2}{*}{ Absorptive basins (164) } & \multicolumn{3}{|c|}{ Evapotranspiration basins } \\
\cline { 3 - 5 } & & Actual results (9) & Statistical results (185) & Total (194) \\
\hline Min. & $1,374.45$ & 502.65 & 36.46 & 36.46 \\
\hline Max. & $314,404.70$ & $132,606.63$ & $673,151.68$ & $673,151.68$ \\
\hline Mean & $23,070.39$ & $41,343.07$ & $13,459.72$ & $14,753.28$ \\
\hline Total & $3,783,543.73$ & $372,087.62$ & $2,490,048.41$ & $2,862,136.03$ \\
\hline
\end{tabular}

The mean precipitation data give no clue as to the maximum and minimum values, and neither do they offer any insight into other parameters, like the duration or intensity of precipitation. In many cases actual rainfall figures are several times higher or lower than the mean calculated for the given period. Presented below are exact measurements and their averages for a few days in the Potok Oliwski catchment, to show how widely they can differ in various time intervals (Fig. 7).

The above observations demonstrate that introducing the actual distribution of precipitation into calculations is a key condition of correct analysis of the remaining elements of the water balance. They also confirm the observations of Wehner et al. [30] or Westra et al. [31].

Also, one should not forget about big diurnal variations in the precipitation measured. This is not only of hydrological, but also of geomorphological significance, because heavy precipitation moulds (transforms) slopes in the catchments of closed basins [32]. Having a detailed record of the distribution of effective precipitation (measurement every half an hour), it is possible to determine the amount of rainwater that appears on the surface of the catchment at any given time interval and that enters further stages of the water cycle in nature [33]. Table 4 presents water volumes calculated for select days in which precipitation varied in terms of intensity. The data are remarkable: during a torrential rain event the figure can skyrocket to more than 26 times the normal amount.

The other chief component of alimentation of closed evapotranspiration basins is that supplied by all groundwater sources [34]. Research on the alimentation of closed basins in the upper Parsęta catchment has been carried out since 1999, and the alimentation index chosen is the concentration of ionised silica in the surface waters of those depressions. On the basis of multi-year observations, their
Table 6 . Amount of rainwater drained by storm sewers depending on rain intensity.

\begin{tabular}{|c|c|c|}
\hline $\begin{array}{c}\text { Normal rain } \\
\text { 18 February 2001 }\end{array}$ & $\begin{array}{c}\text { Heavy rain } \\
\text { 12 March 2001 }\end{array}$ & $\begin{array}{c}\text { Torrential rain } \\
\text { 9 July 2001 }\end{array}$ \\
\hline \multicolumn{3}{|c|}{ Amount of water in built-up areas } \\
\hline $6,090 \mathrm{~m}^{3}$ & $14,790 \mathrm{~m}^{3}$ & $160,950 \mathrm{~m}^{3}$ \\
\hline \multicolumn{3}{|c|}{ Amount of water drained by storm sewers } \\
\hline $3,654 \mathrm{~m}^{3}$ & $8,874 \mathrm{~m}^{3}$ & $96,570 \mathrm{~m}^{3}$ \\
\hline
\end{tabular}

alimentation has been classed as a precipitation-groundwater type. Alimentation by groundwater predominates during the spring periods of an intensive snowmelt and in the early autumn after rainfalls, causing a rapid rise of the groundwater table [6]. Alimentation by precipitation predominates in the remaining seasons of the year, with special intensity in the summer half-year.

Another important aspect of variations in the water resources of closed basins is loss of water due to infiltration. Predominant in the substratum of postglacial areas of Northern Poland are easily permeable sand deposits. Land depression without a surface outflow of water are, against appearances, open systems receiving a constant inflow of matter via atmospheric supply, but there is also a considerable underground outflow [35]. Thus, in the case of evapotranspiration areas without an outlet, among the dominant processes is not only evaporation, but also percolation, which attains a substantial volume [36]. This has been corroborated by water balance studies in the upper Parsęta catchment [6] and in the catchments with no outflow of the Kashubian (northern Poland) hydrographic system [27]. 


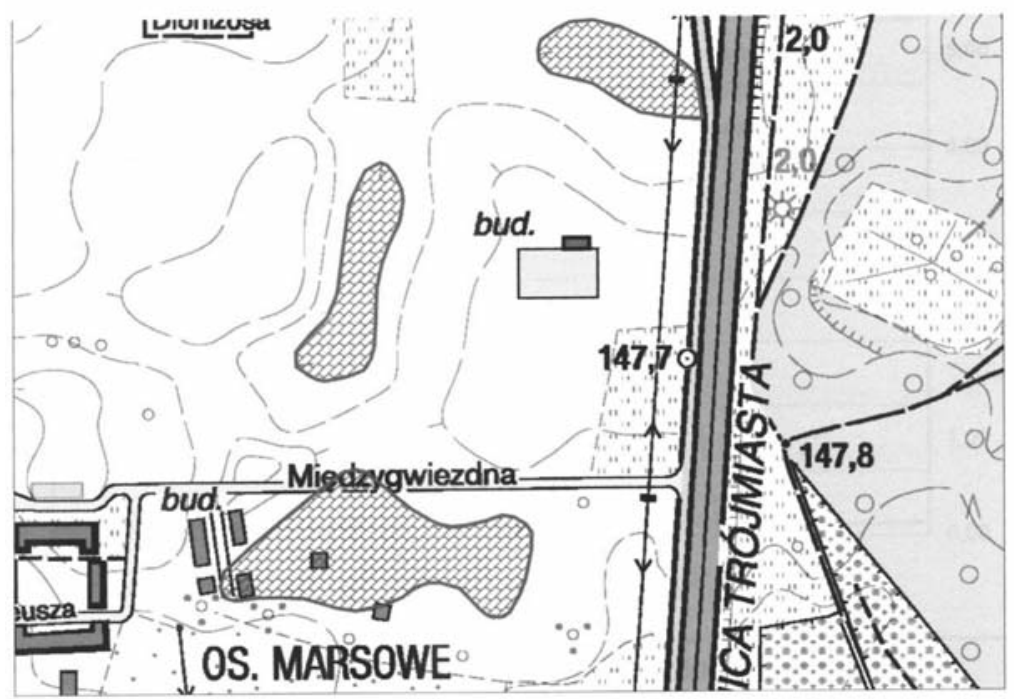

Fig. 8. Example of the location of basins for rainwater storage.

The volumes of the closed basins, and hence their potential storage capacities, were estimated by a statistical method employing Peck's formula and, in the next stage, equations of linear functions.

The total capacity of all the closed basins in the upper Parsęta catchment amounted to $6,645,679.76 \mathrm{~m}^{3}$. The storage potential of absorptive basins was decidedly greater, at $3,783,543.73 \mathrm{~m}^{3}$, varying between $1,374.45 \mathrm{~m}^{3}$ and $314,404.70 \mathrm{~m}^{3}$. Those figures were calculated for 164 depressions (Table 5).

The total volume of closed evapotranspiration basins accounted for a mere $43 \%$ of the storage capacity of all the closed basins in the upper Parsęta catchment. As calculated for 194 cases, it averaged 2,862,136.03 $\mathrm{m}^{3}$ and ranged from $36.46 \mathrm{~m}^{3}$ to $673,151.68 \mathrm{~m}^{3}$ (Table 5) [26].

In the case of closed evapotranspiration basins, the figures were calculated again when the set was broken down into nine small depressions for which two parameters were available: area and depth, and the remaining 185 basins. The combined volume of the nine depressions equalled $372,087,62 \mathrm{~m}^{3}$ and ranged from $502.65 \mathrm{~m}^{3}$ to $132,606.63 \mathrm{~m}^{3}$. The total storage capacity of the 185 basins whose depths

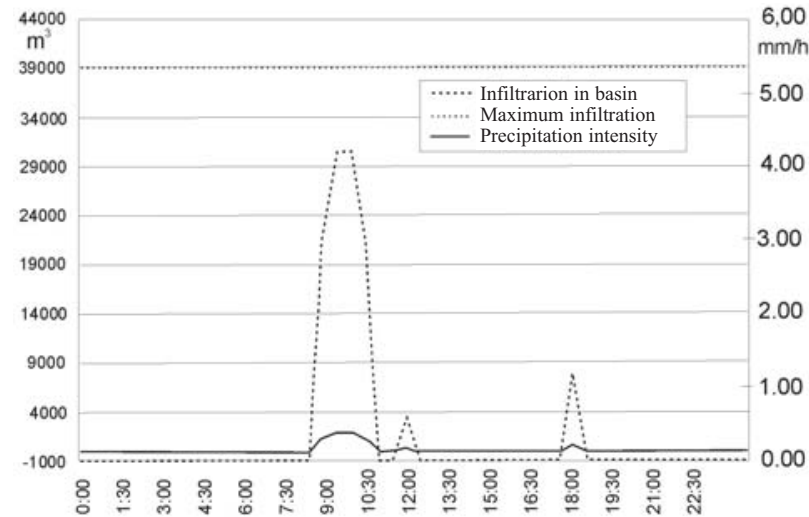

Fig. 9. Infiltration versus precipitation on 18 February 2001. were calculated by the statistical method was estimated at 2,490,048.41 $\mathrm{m}^{3}$ (Table 5).

On the basis of calculations making use of Penck's formula, it was found that the total volume of closed evapotranspiration basins in the Potok Oliwski catchment was $1,677.1 \mathrm{~m}^{3}$ (ranging from 74.3 to $739.2 \mathrm{~m}^{3}$ ). In turn, when filled with water, absorptive basins would have a total volume of $23,182.8 \mathrm{~m}^{3}$ (ranging from 34.7 to $5,362.5 \mathrm{~m}^{3}$; Table 1).

Depending on the intensity of rain (Table 6), the upland $\left(7.25 \mathrm{~km}^{2}\right)$ can receive varying amounts of water within an hour. A proportion of water from built-up areas reaches storm sewers, as follows:

The alternative way of managing rainwater thus estimated was based on the level of permeability of surficial deposits, and in consequence on water infiltration, with three stages of retention: from surface to underground storage [37]. A significant, if not the most important on a local scale is surface runoff [38]. Geological boreholes drilled on the upland show it to consist of thick varigrained sand deposits, intercalations of till, and gravels [39]. When considering absorptive basins as sites where rainwater might be

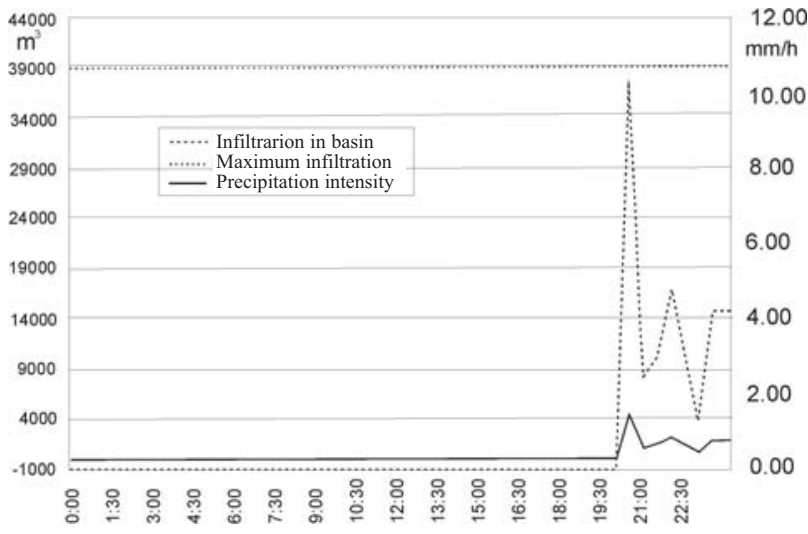

Fig. 10. Infiltration versus precipitation on 12 March 2001. 


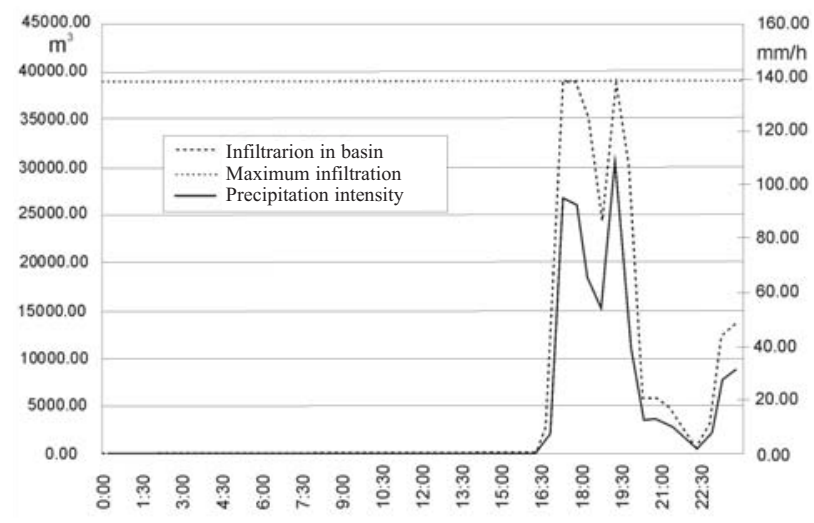

Fig. 11. Infiltration versus precipitation on 9 July 2001.

stored, it was assumed that the deposits building them had good or average permeability. Darcy's formula [40] was used to check the filtration flow intensity in terms of volume, and hence the capacity of water for infiltration in the depressions, and then the necessary area was established that rain of various intensity would infiltrate. It turned out to range from $1,015 \mathrm{~m}^{2}$ for normal rain to $26,825 \mathrm{~m}^{2}$ for torrential rain. It should be remembered that this range of basin area fits the current level of building in the upland part of the catchment; it can be adjusted to changing needs both in terms of precipitation intensity and the extent of the built-up area it is supposed to serve, e.g. by utilising a cluster of several smaller depressions or by slightly deepening $(0.5 \mathrm{~m})$ a single larger one (Fig. 8).

With their areas of $12,300 \mathrm{~m}^{2}, 4,900 \mathrm{~m}^{2}$, and 4,500 $\mathrm{m}^{2}$, respectively, the depressions chosen as examples of reservoirs for the entire built-up part of the catchment meet the above requirements as to the infiltration area (Fig. 9). It is only in the case of a one-hour torrential rain that would make it necessary to deepen one of them or divide this amount of rainwater between them and an additional depression.

To test the effectiveness of retention in depressions in a 24-hour infiltration period, three of them were selected with a total area of $21,700 \mathrm{~m}^{2}$ and a volume of $7,230 \mathrm{~m}^{3}$. For a normal rain (18 February 2001), the amount of water that accumulated in them as a result of precipitation within this period infiltrated with no time lag: the infiltration volume equalled the rainfall volume (Fig. 9). The infiltration reached $1,865.81 \mathrm{~m}^{3} / 30 \mathrm{~min}$ that day, which was a mere $4.8 \%$ of the maximum figure. Similarly for a heavy rain (12 March 2001), water infiltration matched its accumulation in the basins, and at $4,531.25 \mathrm{~m}^{3}$ it did not even approach the maximum, reaching just $11.6 \%$ of the potential figure (Fig. 10).

The last day selected for analysis was 9 July 2001, with especially heavy precipitation that caused a flood in the Gdańsk area. An analysis of the infiltration figures and volumes of water accumulating in the basins showed that on that day the maximum infiltration value was achieved three times and lasted 1.5 hours; in the remaining period it was lower. The quantities of water that did not manage to infiltrate were $3,587.04 \mathrm{~m}^{3}$ at 17:00, 5,574.82 $\mathrm{m}^{3}$ at 17:30, and
10,250.64 $\mathrm{m}^{3}$ at 19:00. But those surpluses infiltrated already half an hour after they had appeared (Fig. 11).

Taking into consideration the parameters of the select basins and the precipitation conditions characteristic of the study area, the above calculations indicate that its filtration conditions are sufficient for the basins to serve as receptacles for rainwater from built-up areas [7]. This means that it would be possible to refrain from interference with the system of surface streams through discharges from storm sewers into them. The water being now drained in this way would naturally stay in the upland part of the catchment, whether retained on the surface or as groundwater alimentation, thus reducing sudden jumps in stream discharges like those after torrential rains, which have been one of the causes of upland-originating floods that threaten the builtup areas in the zone of the abrasion platform [41].

\section{Conclusion}

In the $20^{\text {th }}$ century there appeared the first signals of freshwater shortages in many parts of the globe. Among them is Poland, with one of the lowest indices of water resources per capita. The situation is no better concerning water resources available to agriculture and industry. In the case of the former, there are regions with scant precipitation, often suffering from droughts. In the latter, the demand for quality water often exceeds its supply. The resources dwindle fast, which follows not only from their consumption, but also from their chemical and biological contamination. One should therefore reflect on how to counteract the rapid changes in the workable water resources intended for economic and household use. One of the possibilities is to employ the retentive function of areas without outlets. However, when considering the accumulation of excess water in closed basins, one should pay special attention to such natural factors as their distribution, morphometric indices, geological structure and the level of permeability of deposits connected with it, and finally atmospheric supply in the form of precipitation of various intensities. Regard for natural conditions is highly significant given the fast advancing development of urban infrastructure which results primarily from building into natural areas and from changes in the land-use pattern. In consequence, there is an accelerated outflow of precipitation water and its unrecoverable loss.

But employing both absorptive and evapotranspiration areas without outlets to accumulate and temporarily store excess rainwater would give people time to use it. In the case of isolated basins, the advantage would be negligible owing to their size and capacity, but a set of many such basins offers a substantial potential for periodic accumulation and storage of rainwater. A good example is the upper Parsęta catchment and the headwater zone of the Potok Oliwski catchment. The analysed basins without outlets are valuable not only in terms of water management, but also of ecological and environmental protection. It is therefore desirable to take all possible measures to protect those objects that can ensure balance in the natural environment at a time of increasing human impact. 


\section{References}

1. CASTRONOVAA.M., GOODALL J.L. A generic approach for developing process-level hydrologic modeling components. Environ. Modell. Softw. 25, (7), 819, 2010.

2. LIU T., WILLEMS P., FENG X.W., LI Q., HUANG Y., BAO A.M., CHEN X., VEROUSTRAETE F., DONG Q.H. On the usefulness of remote sensing input data for spatially distributed hydrological modelling: case of the Tarim River basin in China. Hydrol. Process. 26, (3), 335, 2012.

3. DÖLL P., KASPAR F., LEHNER B. A global hydrological model for deriving water availability indicators: model tuning and validation. J. Hydrol. 270, (1-2), 105, 2003.

4. KRYSANOVA V., HATTERMANN F., WECHSUNG F. Development of the ecohydrological model SWIM for regional impact studies and vulnerability assessment. Hydrol. Process. 19, (3), 763, 2005.

5. BROOKS T.R. Weather - related effects on woodland vernal pool hydrology and hydroperiod. Wetlands. 24, (1), 104, 2004.

6. MAJOR M. Effect of weather conditions on the amount of pollutants supplied to experimental catchments of the IMNE network in the hydrological years 2006-2007. In: Z Szwejkowski (Ed.), Environmental aspects of climate change. University of Warmia and Mazury, Olsztyn, pp. 135-149, 2009.

7. MAJOR M., CIEŚLIŃSKI R. Weather conditions, their effect on the chemical composition of surface water in closed basins and their consequences for water management: The case of the upper Parseta and Potok Oliwski catchments (Northern Poland). GeoActa. 9, 67, 2010.

8. BROOKS T.R., HAYASHI M. Depth-area-volume and hydroperiod relationships of ephemeral (vernal) forest pools in southern New England. Wetlands. 22, (2), 247, 2002.

9. BROOKS R.T. A review of basin morphology and pool hydrology of isolated ponded wetlands: implications for seasonal forest pools of the northeastern United States. Wetlands Ecology and Management. 13, 335, 2005.

10. KALLIS G., BUTLER D. The EU water framework directive: measures and implications. Water Policy. 3, (2), 125, 2001.

11. OKI T., KANAE S. Global Hydrological Cycles and World Water Resources. Science. 313, (5790), 1068, 2006.

12. THAKUR J.K., SRIVASTAVA P.K., SINGH S.K., VEKERDY Z. Ecological monitoring of wetlands in semi-arid region of Konya closed Basin, Turkey. Regional Environmental Change. 12, (1), 133, 2012.

13. VÖRÖSMARTY C.J., GREEN P., SALISBURY J., LAMMERS R.B. Global Water Resources: Vulnerability from Climate Change and Population Growth. Science. 289 (5477), 284, 2000.

14. ARNELL N.W. Climate change and global water resources: SRES emissions and socio-economic scenarios. Global Environmental Change. 14, (1), 31, 2004.

15. CHRISTENSEN N.S., WOOD A.W., VOISIN N., LETTENMAIER D.P., PALMER R.N. The Effects of Climate Change on the Hydrology and Water Resources of the Colorado River Basin. Climatic Change. 62, (1-3), 337, 2004.

16. LOWENSTEIN T.K., RISACHER F. Closed Basin Brine Evolution and the Influence of $\mathrm{Ca}-\mathrm{Cl}$ Inflow Waters: Death Valley and Bristol Dry Lake California, Qaidam Basin, China, and Salar de Atacama, Chile. Aquat. Geochem. 15, (1-2), 71, 2009.

17. GAŁCZYŃSKA M., GAMRAT R., PACEWICZ K. Influence of Different Uses of the Environment on Chemical and Physical Features of Small Water Ponds. Pol. J. Environ. Stud. 20, (4), 885, 2011.
18. KRYZA M., WERNER M., DORE A.J., BŁAŚ M., SOBIK M. The role of annual circulation and precipitation on national scale deposition of atmospheric sulphur and nitrogen compounds. J. Environ. Manage. 109, 70, 2012.

19. KARCZEWSKI A. Spatial arrangement of morainic plateau levels of the northern sloping surface in Pomerania as a result of varying deglaciation. Quaest. Geogr. 1, 99, 1985

20. KARCZEWSKI A. Morphogenesis of the marginal zone of the Pomeranian stage on the Parsęta lobe in the Vistulian (Central Pomerania). Ser. Geogr., Nr 44, Wyd. Nauk. UAM, Poznań, 1989 [In Polish].

21. KOSTRZEWSKI A. Integrated Monitoring of the Natural Environment. Storkowo Base Monitoring Station. Biblioteka Monitoringu Środowiska, Warszawa 1994 [In Polish].

22. CHOIŃSKI A. Conditions of water circulation in the upper Parsęta catchment. [In:] A. Kostrzewski, (Ed.), Operation of geoecosystems of river basins. Natural environment of the upper Parsęta catchment: State of research, development, protection. Vol. 1, Poznań: 36-51, 1998 [In Polish].

23. SZPIKOWSKI J. Man-made transformation of the relief of the Perznica river basin in the Neo-Holocene (Drawa Lakeland, Parsęta catchment). Wyd. Nauk. UAM, Poznań, pp. 209, 2010 [In Polish].

24. CIEŚLIŃSKI R. Calculations of the value of retention in a small head-water catchment of the edge zone using Mike She model. Landschaftsökologie und Umweltforschung. 50, 59, 2009.

25. MAJOR M. General systems theory and the operation of basins without an outlet: A methodological aspect. Limnological Review. 12, (2), 71, 2012.

26. MAJOR M. Operation of closed basins in different morpholithological conditions (Parsęta catchment, West Pomerania). Studia i Prace z Geografii i Geologii 27, Bogunki Wydawnictwo Naukowe, Poznań, pp. 232, 2012 [In Polish].

27. DRWAL J. Formation and organisation of the hydrographic network as a basis of assessment of the structure of runoff in postglacial areas. Z. Nauk. Rozpr. i Monogr. UG, 33, pp. 1130, 1982 [In Polish].

28. COOK S.J., SWIFT D.A. Subglacial basins: Their origin and importance in glacial systems and landscapes. EarthScience Reviews. 115, (4), 332, 2012.

29. LUPIKASZA E. Relationships between occurrence of high precipitation and atmospheric circulation in Poland using different classifications of circulation types. Physics and Chemistry of the Earth, Parts A/B/C. 35, (9-12), 448, 2010.

30. WEHNER M.F., SMITH R.L., BALA G., DUFFY P. The effect of horizontal resolution on simulation of very extreme US precipitation events in a global atmosphere model. Climate Dynamics. 34, (2-3), 241, 2010.

31. WESTRA S., ALEXANDER L.V., ZWIERS F.W. Global Increasing Trends in Annual Maximum Daily Precipitation. J. Climate. 26, 3904, 2013.

32. KOO M.S., HONG S.Y. Diurnal variations of simulated precipitation over East Asia in two regional climate models. Journal of Geophysical Research: Atmospheres (19842012). 115, (D5), 2010. DOI: 10.1029/2009JD012574

33. YIN S., LI W., CHEN D., JEONG J.H., GUO W. Diurnal variations of summer precipitation in the Beijing area and the possible effect of topography and urbanization. Adv. Atmos. Sci. 28, (4), 725, 2011.

34. GUNKEL A., LANGE J. New Insights Into The Natural Variability of Water Resources in The Lower Jordan River Basin. Water Resour. Manag. 26, (4), 963, 2011. 
35. WENCHAO S., HIROSHI I., SATISH B. Towards improving river discharge estimation in ungauged basins: calibration of rainfall-runoff models based on satellite observations of river flow width at basin outlet. Hydrology and Earth System Sciences Discussions. 7, (3), 3803, 2010.

36. BARTOLINI E., ALLAMANO P., LAIO F., CLAPS P. Runoff regime estimation at high-elevation sites: a parsimonious water balance approach. Hydrol. Earth Syst. Sci. Discuss. 8, 957, 2011.

37. TINER R.W., BERGQUIST H.C., DEALESSIO G.P., STARR M.J. Geographically Isolated Wetlands: A Preliminary Assessment of their Characteristics and Status in Selected Areas of the United States. U.D. Department of the Interior, Fish and Wildlife Service, Northeast Region, Hadley, MA, 2002.

38. PINIEWSKI M., ACREMAN M.C., STRATFORD C.J., OKRUSZKO T., GIEŁCZEWSKI M., TEODOROWICZ
M., RYCHARSKI M., OSWIECIMSKA-PIASKO Z. Estimation of Environmental Flows in Semi-Natural Lowland Rivers - the Narew Basin Case Study. Pol. J. Environ. Stud. 20, (5), 1281, 2011.

39. MORENO-MATEOS D., MANDER Ü., COMÍN F.A., PEDROCCHI C., UUEMAA E. Relationships between Landscape Pattern, Wetland Characteristics, and Water Quality in Agricultural Catchments. J. Environ. Qual. 37, (6), 2170, 2008.

40. HUA G.F., ZHU W., ZHAO L.F., HUANG J.Y. Clogging pattern in vertical-flow constructed wetlands: Insight from a laboratory study. J. Hazard. Mater. 180, (1-3), 668, 2010.

41. MAASSEN S., BALLA D., KALETTKA T., GABRIEL O. Screening of prevailing processes that drive surface water quality of running waters in a cultivated wetland region of Germany-A multivariate approach. Sci. Total Environ. 438, 154, 2012. 